\title{
Innovation of Training Mode for Special Talents of Electronic Design
}

\author{
Chunyue PAN \\ Department of Electronic and Electrical Engineering \\ Wenzhou Vocational \& Technical College \\ Wenzhou, Zhejiang, China \\ 603199516@qq.com
}

\begin{abstract}
The cultivation of talented people is an important index to measure the quality of teaching quality. Through the investigation of enterprises and the analysis of occupational positions, this paper puts forward design scheme of training mode for special talents of electronic design, innovating the training mode of electronic design talents, and introducing the training effect of electronic design talents.
\end{abstract}

Keywords-electronic design; occupational ability; special talents; Training mode

\section{INTRODUCTION}

The Electronic Information Engineering Technology specializes in training high technology applied talents, such as electronic product design, production management, technology service and so on, facing the first line of enterprise production. But the technical department of the general enterprise, the production department and the marketing center have their own specifications ${ }^{[1]}$. According to the survey of enterprises over the years, employers need innovative talents with electronic design ability. However, due to the limitation of current electronic professional training programs, it is more difficult to train top notch talents. Therefore, the innovation of training mode for special talents of electronic design and the concentration of outstanding teachers to cultivate electronic design talents will solve the problem for the enterprise, bring brand effect to the school and help students get used to work quickly after employment, adapt to the work faster and gain better development prospects.

\section{ThE DETERMinAtion OF The TARGET OF TALENT TRAINING [2]}

\section{A. Enterprise demand analysis}

From the analysis of the graduate tracking survey, the employment posts of the electronic information engineering students are enterprise technology department, production department and marketing center. A student employment statistics show that $55.6 \%$ engaged in technical work, $22.2 \%$ in production management work, and $22.2 \%$ in marketing work, as shown in Figure 1. On analyzing the group of students engaged in technical work, we found that enterprises not only need general technicians, but also need talents with innovative ability of electronic design.
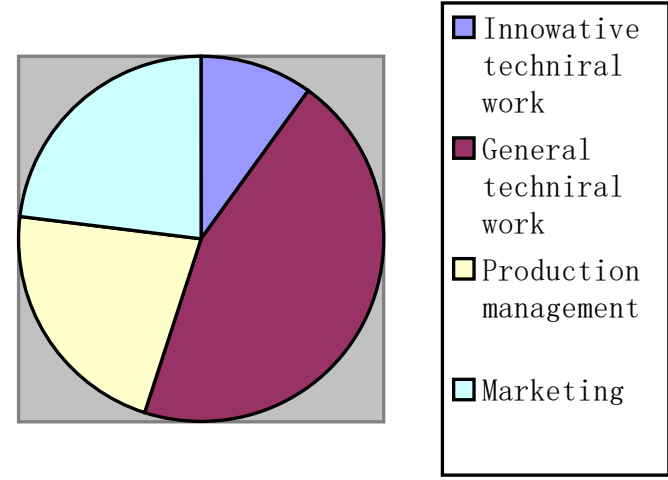

Fig. 1. Statistical map of students' employment post

\section{B. Academic analysis}

From the analysis of the actual teaching situation for many years, higher vocational students have large individual differences in quality and different degree of learning input. If it is the same pattern, it is obvious that it is impossible to train the students to fully meet the needs of the various positions of the enterprise. Therefore, hierarchical training is an inevitable choice. Secondly, due to the limitation of the training plan of electronic information engineering technology professional talents, training top-notch personnel is more difficult. If we can focus on excellent teachers to train electronic design talents, we can enhance students' professional competitiveness, and provide top-notch electronic design talents for enterprises, and bring brand effect to majors and colleges. In addition, the freshman academic situation shows that only part of the students love studying technical problems, and the other part of the students seem relatively weak to accept professional knowledge $\mathrm{e}^{[3]}$.Therefore, according to the wishes of students, setting up specialty classes to guide some students to carry out research learning is the need to explore innovative education mode in higher vocational colleges, as well as the need to cultivate their personality traits.

In a word, adhere to the employment oriented to social needs as the goal, the abstraction and the integration of curriculum system and implementation of training mode for special talents will enhance students' ability of autonomous learning ability, electronic technology application and creative 
practice significantly in accordance with the required capacity and quality requirements.

\section{DESIGN OF TRAINING PROGRAM FOR ELECTRONIC SPECIAL TALENTS}

\section{A. Determine the goal of talent training}

According to the research of enterprises and demand analysis of personnel positions, students who have "special ability of electronic design" mainly engaged in innovative design work of electronic products after graduation. Through the analysis of the typical job task, it is clear that the students' professional ability requirements are shown in Table I. According to the demonstration of the professional construction guidance committee, the training goal of "special ability of electronic design" is determined : on the basis of students' original major, through specialized training, we can further strengthen students' professional skills, improve students' self-learning ability, promote talents cultivation, cooperate with industries and associations and cultivate students who have excellent professional ethics, adapt to the product design and production in the field of electronic engineering ${ }^{[4]}$.
TABLE I. OCCUPATIONAL SCOPE- CORE JOBS- CORE COMPETENCE

\begin{tabular}{|c|c|c|}
\hline $\begin{array}{l}\text { Occupational } \\
\text { scope }\end{array}$ & Core jobs & Core competence \\
\hline $\begin{array}{l}\text { Design and } \\
\text { development } \\
\text { of electronic } \\
\text { products }\end{array}$ & $\begin{array}{c}\text { Product } \\
\text { design } \\
\text { technician, } \\
\text { Electronic } \\
\text { Engineer }\end{array}$ & $\begin{array}{l}\text { (1) The ability to manufacture and } \\
\text { analyze electronic circuits. } \\
\text { (2) The application and design ability of } \\
\text { the single chip microcomputer system; } \\
\text { (3) Electrical schematic diagram, printed } \\
\text { circuit board drawing design ability; } \\
\text { (4)The debugging ability of hardware } \\
\text { circuit and software; } \\
\text { (5) The design ability of electronic } \\
\text { product process documents. }\end{array}$ \\
\hline
\end{tabular}

B. Construction of curriculum systems ${ }^{[5]}$

Information engineering technology is shown in Table II. The core jobs of students with "Special ability of electronic design" are electronic product design technicians and electronic engineers. Therefore, after analyzing its core competencies, we should increase courses for training electronic design skills on the basis of existing courses of electronic information product design. The corresponding curriculum system is shown in Table III.

TABLE II. THE COURSE SYSTEM OF THE DESIGN DIRECTION OF ELECTRONIC INFORMATION PRODUCTS

\begin{tabular}{|c|c|c|}
\hline \multicolumn{2}{|c|}{ Curriculum type } & Curriculum name \\
\hline \multirow{5}{*}{$\begin{array}{l}\text { General } \\
\text { knowledge } \\
\text { course }\end{array}$} & $\begin{array}{l}\text { Ideological and Political } \\
\text { Education }\end{array}$ & $\begin{array}{l}\text { An introduction to Mao Zedong thought and the theory system of socialism with Chinese characteristics, } \\
\text { Ideological and moral cultivation and legal basis, Situation and Policy Education }\end{array}$ \\
\hline & Health and safety education & Sports and health, Military training \\
\hline & $\begin{array}{l}\text { Career development and } \\
\text { employment guidance } \\
\text { education }\end{array}$ & Career development and employment guidance \\
\hline & Cultural basic education & practical English, Advanced application of office software, Mathematics \\
\hline & Quality development course & public elective course \\
\hline \multirow{4}{*}{$\begin{array}{l}\text { Professional } \\
\text { courses }\end{array}$} & Professional basic courses & The programming of C language, circuit analysis, Analog electronic technique, Digital electronic technology \\
\hline & Major core courses & $\begin{array}{l}\text { Application technology of single chip microcomputer, Design and practice of electronic system, Production } \\
\text { technology of electronic products, C51 program design, Development of small intelligent electronic products }\end{array}$ \\
\hline & $\begin{array}{l}\text { Professional development } \\
\text { course }\end{array}$ & $\begin{array}{l}\text { Design and manufacture of printed circuit board, Electronic measurement technology, High frequency } \\
\text { electronic technology, power electronic technology, Programmable logic device and its application, Shape } \\
\text { design of small electronic products, Electronic product marketing }\end{array}$ \\
\hline & Professional practice course & $\begin{array}{l}\text { Integrated practical training of Electrical Technology, Integrated practical training of electronic technology, } \\
\text { Radio mounting skill training, Professional social practice, Graduation comprehensive practice }\end{array}$ \\
\hline
\end{tabular}

TABLE III. THE TRAINING COURSE SYSTEM FOR THE SPECIAL STUDENTS

\begin{tabular}{|c|c|c|c|c|}
\hline Number & Curriculum name & Curriculum nature & Opening time & Main teaching forms \\
\hline 1 & Electronic circuit making and debugging & Practice Teaching & $\begin{array}{l}\text { First grade summer } \\
\text { vacation }\end{array}$ & Project teaching, centralized training \\
\hline 2 & Design and implementation of FPGA & $\begin{array}{l}\text { Integration of theory and } \\
\text { reality }\end{array}$ & Third term & Project teaching, centralized training \\
\hline 3 & $\begin{array}{l}\text { Application of high performance single chip } \\
\text { microcomputer }\end{array}$ & $\begin{array}{l}\text { Integration of theory and } \\
\text { reality }\end{array}$ & Fourth term & Project teaching, centralized training \\
\hline 4 & Electronic system project training & Practice Teaching & $\begin{array}{l}\text { Summer vacation in } \\
\text { grade two }\end{array}$ & Project teaching, centralized training \\
\hline 5 & $\begin{array}{l}\text { Research and development of intelligent } \\
\text { electronic products }\end{array}$ & Practice Teaching & Fifth term & $\begin{array}{l}\text { Inquiry learning, teacher and } \\
\text { apprentice form }\end{array}$ \\
\hline
\end{tabular}

After completing the professional basic courses, the students will be selected according to the students' wishes and the results of the first school year.
IV. IMPLEMENTATION AND EFFECTIVENESS OF THE TRAINING OF SPECIFIC ELECTRONIC DESIGN TALENTS

\section{A. Selection of student}

In order to ensure that students with electronic design expertise can achieve good results, an open selection among 
all majors in the department will begin at the end of the second semester, which is divided into three steps.

The first step: Selection preparation. Students of 3:1 quota are selected by students' signing up voluntarily and teachers and class teachers' jointly recommending. At the same time, the Department set up an expert group.

The second step: selection. The expert group conducted the theoretical assessment and practical operation assessment to the enrolled students. students.

The third step: admission. Confirm the admission of 18

Students are required to have a higher degree of professional recognition, hard work, and a relatively strong interest in electronic design and practical ability. In the course of teaching, students will be eliminated and adjusted. The elimination principle is the survival of the fittest and the wishes of the students ${ }^{[6]}$.

\section{B. The protection of teachers' strength}

In order to ensure the effective cultivation of the special students, teachers who gives classes to special training course should be selected carefully and have "double-qualified teachers" qualification, have cooperative projects or other scientific research projects and carry out the teaching idea of the integration of production, learning and research.

\section{Teaching implementation}

1) The teaching design and implementation of the routine teaching course

The teaching course of the general specialty consists of three parts, which are basic courses, core courses and professional development courses. Professional basic course learning, training the basic ability of professional is the industry general ability. The learning of professional direction courses, training students' professional core competence is special ability. The learning of professional development courses is to cultivate students' professional development ability. We should carry out the teaching reform of "learning by doing, doing by learning" and "learning and doing together" in order to integrate theoretical knowledge and practical skills. We will carry out project teaching to improve the students' interest in learning and the quality of teaching ${ }^{[7]}$.

2) The teaching design and implementation of the training course of the special ability

The learning of Special ability of electronic design training course mainly implements the teaching mode of "learning by doing" and " learning by exploring", so as to cultivate students' ability of independent learning and innovation.

\section{Implementation effect}

The implementation of the training program of "electronic design skills" has achieved two wishes of all teachers in the electronic profession, one is the high quality employment of students in technical department of famous enterprises; the other is that students in all kinds of competitions.

Through investigation, the first electronic design special class graduates has good employment quality and high salary. The survey data show that the professional counterpart of the special students is paid more than 3000 Yuan or up to 10000 Yuan a month after graduation.

The professional ability and comprehensive quality of students majoring in electronic information engineering technology have been significantly improved. The employment rate and employment level of graduates are relatively high. The social employing units have a high evaluation of graduates' professional quality, professional ability, cultural quality and physical and psychological quality.

Students get honors in many competitions. For example, in 2014, they got good results in students' Electronic Design Competition (TI cup) in Zhejiang province, wining one first prize and three two prize. In 2017, they was awarded two first prize, two second prize and one award for three in the National College Students' electronic design competition.

\section{CONCLUSION}

Through the implementation of "special ability of electronic design" talent training program, students' comprehensive quality and professional competitiveness have been significantly improved, so as to establish a good foundation for their career development after graduation. It also sets up a professional brand effect for the school, and gets the favor of many employers. It has been proved by practice that the training mode of "Special ability of electronic design" is a practical and feasible way to cultivate high-quality talents of electronic information engineering technology.

\section{REFERENCES}

[1] XIE Li. Research and practice of talent training program for electronic information specialty in Higher Vocational Education[J], Journal of Chongqing Electric Power College,2013(2) :10-12.

[2] GAO Fang, WANG xueli, WANG di. Research on training program design of Applied Electronic Technology Professionals [J],Education and profession,2010(11):115-116.

[3] PAN Chunyue, Design and Carry Out the Talent Training Scheme about Two Arrangement and Multi-derection in Electronics and Information Engineering [J], Career time and space,2013.(10)

[4] DI Zhi Hua,GE Yun Ping, Construction and implementation of talen training program for Applied Electronic Technology Specialty in Higher Vocational Education [J], Education and profession,2011(10)

[5] HOU Yi Feng, Research and practice of personnel training program and employment in electronic information engineering $[\mathrm{J}]$, Scientific and technological information,2009(9).

[6] XIO GuoHua. Some thoughts on the cultivation of the specialty of mould specialty in Higher Vocational Education[J], Mechanical Vocational Education,2014(1)

[7] ZOU Fang. Study on the cultivation mechanism of the extra-long students[J], Out of school education in China ,2010(7) 